\title{
Five amphibian mortality events associated with ranavirus infection in south central Ontario, Canada
}

\author{
Amy L. Greer ${ }^{1, *}$, Michael Berrill ${ }^{2}$, Paul J. Wilson ${ }^{2,3}$ \\ ${ }^{1}$ Watershed Ecosystems Graduate Program, Trent University, 1600 West Bank Dr., Peterborough, Ontario K9J 7B8, Canada \\ ${ }^{2}$ Department of Biology, Trent University, 1600 West Bank Dr., Peterborough, Ontario K9J 7B5, Canada \\ ${ }^{3}$ Natural Resources DNA Profiling and Forensic Centre, Trent University, 1600 West Bank Dr., Peterborough, \\ Ontario K9J 7B5, Canada
}

\begin{abstract}
Using field, molecular and histological methods, an epizootic, systemic disease causing death within wood frog Rana sylvatica tadpoles and leopard frog Rana pipiens metamorphs at 3 different locations within Southern Ontario, Canada, has been investigated. Our results demonstrated that the probable cause of this disease was a ranavirus. Affected amphibians were found to exhibit necrosis within the hematopoietic cells. Liver tissue samples were found positive for the virus by PCR amplification of the ranavirus (Family: Iridoviridae) major capsid protein (MCP). Positive samples were confirmed by sequence analysis. Clinically normal, laboratory-raised wood frog egg broods were also found to test weakly positive for ranavirus. The population effects of disease on these amphibian communities have not yet been conclusively associated with population declines, but warrant more focused consideration.
\end{abstract}

KEY WORDS: Frog · Rana sylvatica · Rana pipiens · Ranavirus · Amphibian · Polymerase chain reaction · Canada

\section{INTRODUCTION}

There is much known about the diseases of wildlife which are economically or recreationally important. However, there is much less known about the diseases of species that do not fall into one of these two categories. Viruses of the family Iridoviridae have been increasingly recognized as a cause of amphibian mortality events (Alford \& Richards 1999, Green et al. 2002). The family Iridoviridae is composed of large DNA viruses with icosahedral capsids (Bollinger et al. 1999, Chinchar \& Mao 2000, Chinchar 2002). Within this virus family there are 5 recognized genera, and Ranavirus is one of the genera that is pathogenic to amphibians, fish and reptiles (Daszak et al. 1999). Ranavirus infections have been found within a wide range of amphibian and fish populations in Australia (Speare \& Smith 1992), Europe (Hyatt et al.
2000), Asia (Marschang et al. 1999), South America (Speare et al. 1991, Zupanovic et al. 1998a) and North America (Bollinger et al. 1999, Green et al. 2002).

The manifestation of ranavirus disease within lower vertebrate species worldwide ranges from inapparent to fatal, and varies depending on the virus and the host species (Chinchar \& Mao 2000). This disease in frogs has been observed to cause mortality rates approaching $100 \%$ in tadpole and metamorphic individuals in several locations (Green et al. 2002). The United States Geological Survey (USGS) has investigated mass mortality events involving amphibians and found that between 1996 and 2001, 31 of 64 occurrences of amphibian illness and death in the USA could be attributed to ranaviral infection, with an additional $9 \%$ being attributed to ranaviral infection combined with another etiology (Green et al. 2002). It is becoming 
apparent that the infection and death of diverse groups of amphibians testing positive for ranavirus is a serious and potentially devastating occurrence.

We report here on the recurring presence of a ranavirus in 3 amphibian populations in Southern Ontario, Canada. The objectives for this work were to determine whether a ranavirus was associated with 5 amphibian mortality events investigated in south central Ontario, Canada. We also examined potential transmission routes for the virus within these populations.

\section{MATERIALS AND METHODS}

Field sites. Tadpoles and recent metamorphs were collected from 5 different sites within Southern Ontario. Field sites can be classified into 2 categories, namely (1) sites where disease was observed and subsequently investigated, and (2) sites where no disease was observed. Disease sites included the James Oliver

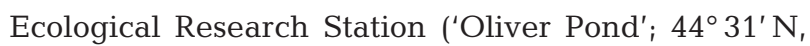
$\left.78^{\circ} 32^{\prime} \mathrm{W}\right)$, The Kortright Centre for Conservation ('Kortright Pond'; 43 $57^{\prime} \mathrm{N}, 79^{\circ} 42^{\prime} \mathrm{W}$ ) and Gannon's Narrows $\left(44^{\circ} 38^{\prime} \mathrm{N}, 78^{\circ} 41^{\prime} \mathrm{W}\right)$. Sites that showed no signs of disease and were used as control sites included the Poplar Pond $\left(44^{\circ} 31^{\prime} \mathrm{N}, 78^{\circ} 32^{\prime} \mathrm{W}\right)$ and the Trent University Archeology Pond $\left(44^{\circ} 21^{\prime} \mathrm{N}\right.$, $78^{\circ} 17^{\prime} \mathrm{W}$ ). To be considered a diseased site, $\geq 10$ ind. had to meet the case definition. This meant that sick and/or dead individuals had to exhibit 4 of 7 clinical signs. Clinical signs included redness in the vent, abdomen, or legs, swollen vent, edema of the body cavity, cutaneous lesions, anorexia and loss of escape behaviour. The Oliver Pond location is unique because there have been 3 consecutive years of similar mass mortality events here. In May 2002, Rana sylvatica egg masses were collected from the Oliver Pond within $12 \mathrm{~h}$ of being laid and reared in the laboratory in 5 gallon (19 l) aquaria containing aged river water.

Collection of animals. Live animals were transported back to the laboratory. Individuals found at the field site that were already dead were transported back to the laboratory on ice, and individuals that were alive and demonstrating signs of disease were transported alive and then euthanized by administering an overdose of tricaine methanesulfonate (Syndel Laboratories). Livers were dissected from all individuals and data were collected on overall body condition including fat bodies, organ colouration and observable lesions. Equipment was decontaminated using a concentrated bleach solution before moving between field sites (Green \& Barry 2001).

Animal husbandry. Laboratory-raised tadpoles were fed cooked spinach and goldfish flakes daily. All aquaria were constantly aerated. Individuals were euthanized at stage 42 by administering an overdose of tricaine methanesulfonate (Syndel Laboratories).

Histopathology. Liver tissue samples were processed for histology using standard histological techniques. Each sample was serially sectioned at $7 \mu \mathrm{m}$, and stained with hematoxylin and eosin. Sections were examined under a light microscope for pathological findings (Bollinger et al. 1999, Marschang et al. 1999).

Molecular diagnostics. DNA was isolated from frozen and preserved liver tissue biopsy samples from both healthy and diseased individuals. Tissues were lysed in $500 \mu \mathrm{l}$ of $1 \times$ lysis buffer and $25 \mu \mathrm{l}$ of Proteinase $\mathrm{K}\left(14.4 \mathrm{mg} \mathrm{ml}^{-1}\right.$, >60.0 U $\left.100 \mathrm{\mu l}^{-1}\right)$. Samples were incubated in a beaker of $65^{\circ} \mathrm{C}$ water in a $37^{\circ} \mathrm{C}$ incubator. After $1 \mathrm{~h}$, a second $25 \mu \mathrm{l}$ of Proteinase $\mathrm{K}$ was added and samples were incubated at $37^{\circ} \mathrm{C}$ overnight. Extractions of total cellular DNA were completed using the standard QIAamp DNeasy Protocol for Animal Tissue (Qiagen). Amplification was conducted using primers specific for a $500 \mathrm{bp}$ fragment of the ranavirus major capsid protein (MCP) (Mao et al. 1997) in $10 \mu \mathrm{PCR}$ reactions. Thermocycling conditions were similar for all samples $\left(94^{\circ} \mathrm{C} 5 \mathrm{~min}, 94^{\circ} \mathrm{C} 30 \mathrm{~s}, 55^{\circ} \mathrm{C} 30 \mathrm{~s}\right.$ and $72^{\circ} \mathrm{C} 30 \mathrm{~s}$, cycled 35 times followed by an extension of $72^{\circ} \mathrm{C} 2 \mathrm{~min}$ ) with the exception of the annealing temperature that was optimized at $60^{\circ} \mathrm{C}$ for leopard frog samples. Both positive controls (plasmid DNA with Ranavirus MCP insert obtained from V. G. Chinchar, Univ. of Mississippi Medical Center, Jackson, MS, USA) and negative controls were tested alongside all unknown samples. All amplified product was visualized by electrophoresis on $1.5 \%$ agarose gels. Sequences of the amplified product were compared to previously published sequences using the NCBI Blast Search nucleotide database. Clustal multiple alignments for viral samples were conducted using BioEdit sequence alignment editor software and then realigned with published Frog Virus 3 (ranavirus) sequences.

\section{RESULTS}

\section{Field observations}

Since 1999, mass mortality events involving tadpoles and new metamorphs have been investigated within Ontario. In total, 5 mortality events have been investigated. These events involved 2 different species of amphibians in 3 different locations within Ontario, and one of these locations has experienced a reoccurring epidemic state. In each location more than 50 individuals meeting the case definition were identified. At the Oliver Pond, Rana sylvatica experienced mass mortal- 


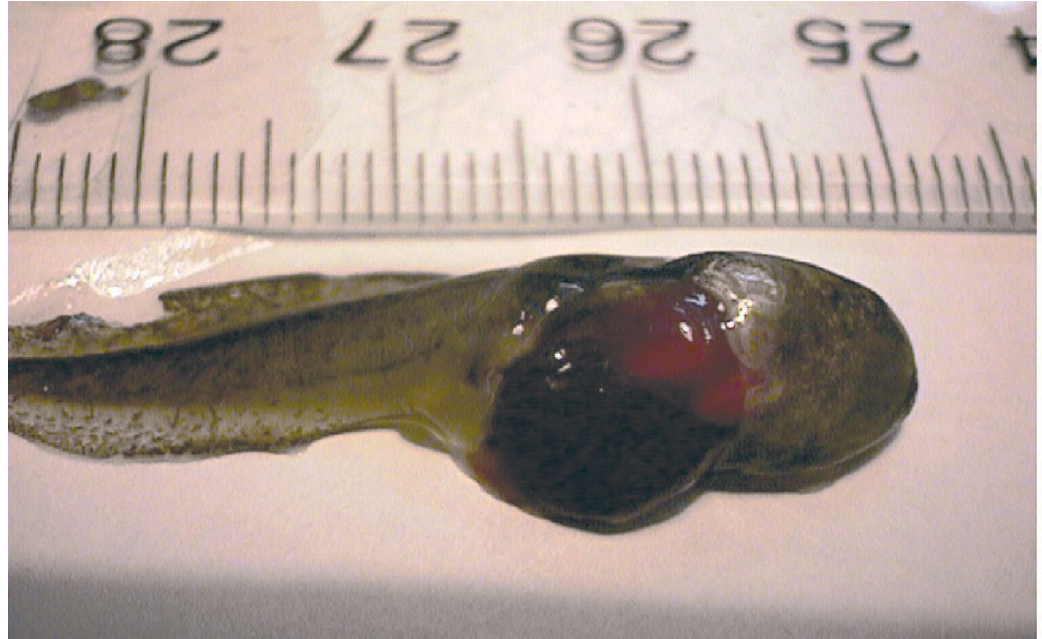

Fig. 1. Rana sylvatica. Example of a systemic hemorrhage

no mortality event was observed at the Oliver Pond during 2002 after 3 previous events.

Histological examination and polymerase chain reaction analysis (PCR) (Table 1) have contributed to the identification of the presence of a ranavirus within these individuals. Sixty percent of the amphibian mortality events investigated were associated with the presence of a ranavirus (Family: Iridoviradae) and occurred at the Oliver Pond in 2001, Kortright Centre in 2001 and Gannon's Narrows in 2002. The remaining $40 \%$ of cases are suspected to be associated with this same virus based on similar clinical signs, location and epidemiological data despite a lack of suitable samples for tissue histology

ity events involving more than 100 individuals in June of 1999, 2000 and 2001. More than 50 Rana sylvatica were found dead at the Kortright Pond in June 2001, and over 100 Rana pipiens metamorphs were found dead at Gannon's Narrows in August 2002. Necropsy observations included edema of the body cavity, poor fat body composition, pale and mottled colouration of the liver and systemic hemorrhage (Fig. 1). Cutaneous lesions and ulcers were not observed. In all mass mortality events, only 1 species of amphibian was involved despite the presence of a diverse amphibian community. In 4 events only tadpoles were infected, and these individuals ranged from Gosner stages 40 to 45 (Gosner 1960). Recent metamorphs were afflicted by only 1 mortality event, and no morbid or dead adults were observed at any of the locations. All 5 of the disease outbreaks in Ontario had onsets within a short timeframe between June and August. No mass mortality events were investigated between September and May. An accurate total number of individuals that succumbed to infection at each location is unknown. However, during 2000 and 2001 no new wood frog metamorphs were observed at the Oliver Pond. Also, or PCR identification. These include mortality events observed at the Oliver Pond in 1999 and 2000. The duration of these die-off events has ranged from several days to several weeks.

\section{Histopathology}

Histological examinations of liver tissue yielded several findings. Disease free leopard frog metamorphs from the Trent University Archeology Pond were found to exhibit normal cellular structure of the liver. Liver tissue in these individuals did not suggest any type of pathology and was subsequently used as control tisse (Fig. 2). Liver tissue sections from leopard frog metamorphs collected from a die-off event at Gannon's Narrows were found to exhibit pathological changes and systemic necrosis of the hematopoietic tissues. Inflammatory cells were observed in the portal tracts, as was ballooning degeneration within the hepatocytes (Fig. 3). All leopard frog livers examined were matched with control livers by Gosner stage to control for any effects of metamorphosis.

Table 1. Diagnostic criteria for amphibian mortality events in south central Ontario, Canada. +: positive result; -: negative result; ND: no data available

\begin{tabular}{|c|c|c|c|c|c|}
\hline Location & Year & $\begin{array}{l}\text { No. ind. meeting } \\
\text { case definition }\end{array}$ & $\begin{array}{c}\text { Abnormal } \\
\text { liver pathology }\end{array}$ & Inclusion bodies & $\begin{array}{c}\% \text { samples positive } \\
\text { by PCR }\end{array}$ \\
\hline Oliver Pond (field) & 2001 & $>100$ & ND & ND & 71 \\
\hline Kortright Pond (field) & 2001 & $>50$ & ND & ND & 93 \\
\hline Oliver Pond (lab-raised) & 2002 & 0 & + & - & 60 \\
\hline Oliver Pond (field) & 2002 & 0 & + & - & 70 \\
\hline Gannon's Narrows (field) & 2002 & $>100$ & + & + & 82 \\
\hline Archeology Pond (field) & 2002 & 0 & - & - & 0 \\
\hline
\end{tabular}




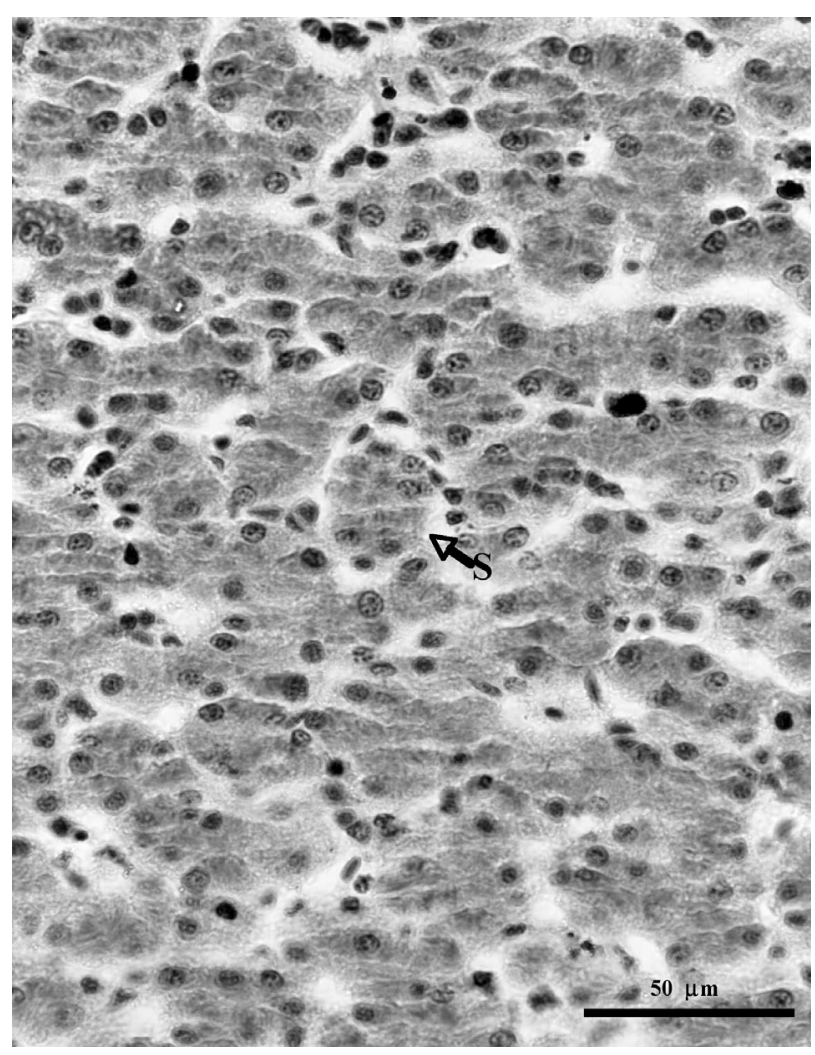

Fig. 2. Rana pipiens. Liver cross section from a normal metamorph collected from Trent University Archeology Pond. Note arrangements of the hepatocytes and sinusoids (S) containing blood cells, radiating throughout

\section{Molecular diagnostics}

Liver tissues collected from individuals meeting the case definition from the Oliver Pond 2001, Kortright Centre 2001, and Gannon's Narrows 2002 events were found to be PCR positive when compared to a known positive control (ranavirus MCP insert in plasmid DNA obtained from V. G. Chinchar). The ranavirus MCPcoding region was also identified in liver tissue obtained from individuals at the Oliver Pond 2002 (both pond-raised and laboratory-raised) that did not meet the case definition. These samples showed no observable disease characteristics but the population had a history of previous mortality events that did meet the case definition and had therefore experienced mortality events in the past. However, individuals from the Archeology Pond, where that have been no observations of unusual morbidity or mortality, were found to test negative by PCR. Representative samples from Oliver Pond 2001, Oliver Pond 2002, Kortright Pond 2001, laboratory-raised Oliver Pond 2002 and Gannon's Narrows 2002 were confirmed positive for ranavirus MCP coding DNA by sequence analysis.

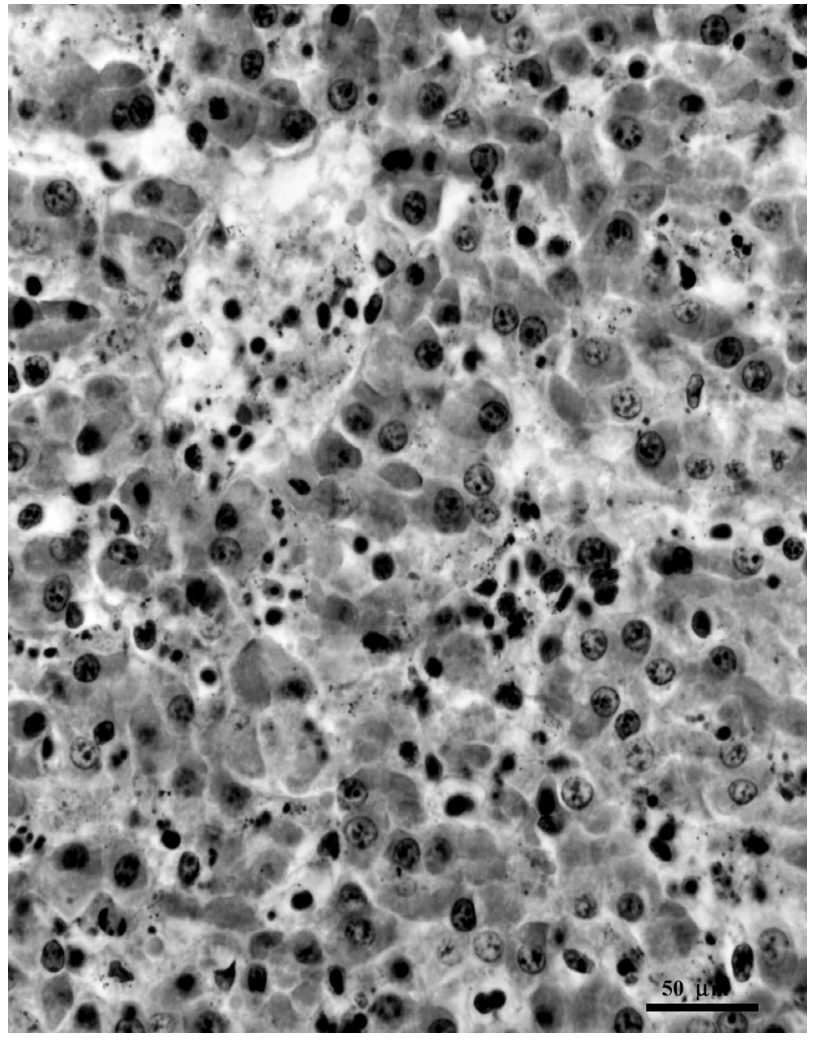

Fig. 3. Rana pipiens. Liver cross section from a Gannon's Narrows metamorph. Ballooning degeneration (hypertrophy) can be observed and is characterized by swelling of cells. This swelling caused sinusoids to become blocked. No open sinusoids can be observed

Sequence analysis revealed that all MCP sequences ( $500 \mathrm{bp}$ ) were a $98 \%$ match to ranavirus (Frog Virus 3) MCP and also indicated that the MCP sequences did not differ among individuals or locations.

\section{DISCUSSION}

Based on field, histological and molecular investigations, a ranavirus may be associated with morbidity and mortality within Ontario amphibian populations. The clinical signs of disease in the individuals examined have similarities to other documented observations from ranavirus infection sites (Carey et al. 1999, Chinchar \& Mao 2000, Chinchar 2002).

The data generated during this study support previous findings that late stage tadpoles and new metamorphs appear more susceptible to ranavirus (Green et al. 2002). Although the pathological findings appear to be significantly different between non-infected and infected Rana pipiens metamorphs, it is important to consider that metamorphosis may cause changes to the liver regardless of viral status. However, this seems 
unlikely since control livers were matched with experimental livers of the same stage and differences were still observed. Metamorphosis may place amphibians at a greater risk of clinical disease from possible ranavirus infection because of the potential for transitory immune deficiency to occur during this time frame. Metamorphosis is arguably one of the more stressful events in the life cycle of an anuran (Barker et al. 1997, Rollins-Smith 1998, Callery et al. 2001). It has been suggested that diminished resilience of the immune system during the transition between tadpole and adult may be a contributing factor to the susceptibility of these amphibians to pathogens at the climax of metamorphosis (Morey et al. 1996); during metamorphosis there may be a window of decreased immune function, at which time these amphibians may be more vulnerable to infections resulting from a pathogenic virus.

Viral positives were observed in lab-reared clinically normal individuals collected as eggs from locations with a history of previous mortality events. Individuals in this category of infection showed no signs of morbidity or mortality. The only linking factor to ranavirus was the historical exposure of the parent frogs. This suggests that in anurans, the possibility of vertical transmission of the virus cannot be ruled out, nor can the selection for resistance among adult frogs previously exposed. There are no published studies that evaluate the possibility of vertical transmission of ranavirus. However, there are reports of other DNA viruses, such as gill associated virus and channel catfish virus, that have demonstrated vertical transmission of virus from adults to eggs (Wise et al. 1988, Brauer 1995, Cowley et al. 2002). It is possible that vertical transmission is occurring in anurans infected with ranavirus based on data collected from this research.

There was no morbidity or mortality observed at the Oliver Pond in 2002 despite 3 annual reoccurrences. Literature sources indicate that in some amphibian populations, ranavirus infection becomes an annually reoccurring problem (Carey et al. 1999). The observation that the Oliver Pond did not have an outbreak in 2002 is significant. Firstly, it is possible that a small number of tadpoles exposed to the pathogen during die-off events in 1999, 2000 or 2001 did not perish due to inherent resistance. These animals would then be the animals observed breeding the following year (Whittington et al. 1997, Zupanovic et al. 1998a,b). The present results for the Oliver Pond are consistent with what would be expected after several years of strong selection for resistance. After several years of this selection, the resulting progeny may no longer be prone to the disease although they may carry the virus at low levels.
Secondly, the Oliver Pond experienced a variety of different weather conditions during the spring of 2002. Therefore, it is possible that the disease was not observed in 2002 because the population was not under the same amount of stress as previous years. There were considerable differences in the water level of the Oliver Pond from 1999 to 2002, with very low water levels observed during the summer of 1999 to 2001 and very high water levels observed in 2002. During times of low water levels, the population density is increased which increases the probability that susceptible individuals will encounter enough (1) infectious agent in the water or (2) infectious individuals to succumb to infection. During times of high water and low population densities, it would be expected that the probability of susceptible individuals encountering infected individuals would be low and, as a result, mass mortalities would not occur within the population.

These theories regarding the observed lack of disease at the Oliver Pond in 2002 allow us to make predictions about what may be observed in years to come. If the disease was not observed because of selection for resistance (strong herd immunity) in 2002, the disease may not occur again at the Oliver Pond, or may be reduced in its prevalence even if the pond experiences abiotic stress. This selection for immunity suggests that the disease itself may not be a major conservation issue, as has been previously suggested. Alternatively, if the population is not strongly selected for immunity and the outbreaks are truly under the control of stress factors, more outbreaks may be observed at the Oliver Pond in the future. Continued monitoring at locations with a history of ranavirus infection will allow the evaluation of long-term data on the frequency and reoccurrence of ranavirus infections of amphibians.

The identification of this virus within Southern Ontario amphibian populations is a significant and unique observation. The data from these 5 outbreaks strongly suggest that these may be the first documented cases of ranavirus in amphibian populations in Ontario, and only the second documented occurrence in Canada. This research is a starting point for the collection of long term data sets that will serve to further characterize the presence of ranavirus within Ontario. In the future, the effect of disease on community stability in the face of constantly changing environmental factors will be of great importance to our understanding and ability to conserve amphibian species.

Acknowledgements. Funding for A.L.G was provided by an Ontario Graduate Scholarship in Science and Technology (OGSST). Fig. 1 photographed by T. Howe. Thanks to V. G. Chinchar at the Universiity of Mississippi Medical Center, Jackson, MS, USA, and the Natural Resources DNA Profiling and Forensic Centre at Trent University. 


\section{LITERATURE CITED}

Alford R, Richards SJ (1999) Global amphibian declines: a problem in applied ecology. Annu Rev Ecol Syst 30: 133-165

Barker KS, Davis AT, Li B, Rollins-Smith LA (1997) In vitro studies of spontaneous and corticosteroid induced apoptosis of lymphocyte populations from metamorphosing Frogs/RU486 inhibition. Brain Behav Immun 11:19-131

Bollinger T, Mao J, Schock D, Brigham RM, Chinchar V (1999) Pathology, isolation and preliminary molecular characterization of a novel Iridovirus from tiger salamanders in Saskatchewan. J Wildl Dis 35:413-429

Brauer F (1995) Models for diseases with vertical transmission and nonlinear population dynamics. Math Biosci 128: $13-24$

Callery E, Fang H, Elinson RP (2001) Frogs without polliwogs: evolution of anuran direct development. BioEssays 23: 233-241

Carey C, Cohen N, Rollins-Smith L (1999) Amphibian declines: an immunological perspective. Dev Comp Immunol 23:459-472

Chinchar VG (2002) Ranaviruses (family Iridoviridae): emerging cold-blooded killers. Arch Virol 147:447-470

Chinchar VG, Mao J (2000) Molecular diagnostics of iridovirus infections in cold blooded animals. Seminars Avian Exotic Pet Med 9:27-35

Cowley JA, Hall MR, Cadogan LC, Spann KM, Walker PJ (2002) Vertical transmission of gill-associated virus (GAV) in the black tiger prawn Penaeus monodon. Dis Aquat Org 50:95-104

Daszak P, Berger L, Cunningham AA, Hyatt AD, Green D, Speare R (1999) Emerging infectious diseases and amphibian population declines. Emerg Infect Dis 5:1-23

Gosner (1960) A simplified table for staging anuran embryos and larvae with notes on identification. Herpetologica 16: 183-190

Green DE, Converse KA, Schrader AK (2002) Epizootiology of sixty-four amphibian morbidity and mortality events in the USA, 1996-2001. Ann NY Acad Sci 969:323-339

Editorial responsibility: Peernel Zwart,

Utrecht, The Netherlands
Hyatt AD, Gould AR, Zupanovic Z, Cunningham AA, Hengstberger S, Whittington RJ, Kattenbelt J, Coupar BEH (2000) Comparative studies of piscine and amphibian iridoviruses. Arch Virol 145:301-331

Mao J, Hendrick RP, Chinchar VG (1997) Molecular characterization, sequence analysis and taxonomic position of newly isolated fish iridoviruses. Virology 229:212-220

Marschang RE, Becher $\mathrm{P}$, Posthaus $\mathrm{H}$, Wild $\mathrm{P}$, Thiel HJ, Muller-Doblies U, Kaletta EF, Bacciarini LN (1999) Isolation and characterization of an iridovirus from Hermann's tortoises (Testudo hermanni). Arch Virol 144: $1909-1922$

Morey SR, Witham CW, Bauder ET, Belk D, Ferren WR, Ornduff R (1996) Pool duration influences age and body mass at metamorphosis in the western spadefoot toad: implications for vernal pool conservation. Ecology, Conservation, and Management of Vernal Pool Ecosystems, Proc Calif Native Plant Soc, Sacramento, CA, p 86-91

Rollins-Smith LA (1998) Metamorphosis and the amphibian immune system. Immunol Rev 166:221-230

Speare R, Smith JR (1992) An iridovirus like agent isolated from the ornate burrowing frog Limnodynastes ornatus in northern Australia. Dis Aquat Org 14:51-57

Speare R, Freeland WJ, Bolton SJ (1991) A possible iridovirus in erythrocytes of Bufo marinus in Costa Rica. J Wildl Dis 27:457-462

Whittington RJ, Kearns C, Speare R (1997) Detection of antibodies against iridoviruses in the serum of the amphibian Bufo marinus. J Virol Methods 68:105-108

Wise JA, Harrell SF, Busch RL, Boyle JA (1988) Vertical transmission of channel catfish virus. Am J Vet Res 49: 1506-1509

Zupanovic Z, Lopez G, Hyatt AD, Green B, Bartran G, Parkes H, Whittington RJ, Speare R (1998a) Giant toads Bufo marinus in Australia and Venezuela have antibodies against 'ranaviruses'. Dis Aquat Org 32:1-8

Zupanovic Z, Lopez G, Hyatt AD, Shiell BJ, Robinson AJ (1998b) An improved enzyme linked immunosorbent assay for detection of anti-ranavirus antibodies in the serum of the giant toad. Dev Comp Immunol 22:573-585

Submitted: October 13, 2004; Accepted: June 17, 2005

Proofs received from author(s): November 1, 2005 